\title{
Innovation Thinking of Socialist core Values Education Pattern in Colleges and Universities
}

\author{
Hongxiang Zhao \\ School of economics and management, Shenyang University of Aeronautics and Astronautics
}

\begin{abstract}
- the colleges and universities to enhance college students the socialist core values is shouldering the important responsibility. In recent years, our country of socialist core values education in colleges and universities attach importance to the extent of the deficiencies in the process of innovation, inadequate propaganda, education idea there is deviation, method of old lag as well as the carrier is too single, lack of innovation in the process of compiling textbooks, teaching staff comprehensive ability, theoretical research is not enough positive problems such as outstanding, urgent needs to solve. Innovation of core socialist values education mechanism, architecture in the process of practice follow the law of "a" in preaching and teaching, achieve the "two into" on to ensure the implementation of effective basis, to create "three mechanism" in the way of education innovation, and methods should adhere to the "four combinations" in enriching education platform,"12345"of architecture "five" to digital form of education, in such a model, to strengthen accelerated promotion institutions of higher learning concept of the core values of socialism education actual effect.
\end{abstract}

Keywords-colleges and universities; values of socialism; thinking and innovation

\section{INTRODUCTION}

At present, the cultivation and practice the socialist core values, is our party's advance of our country socialism great cause, to realize my "China dream" the Chinese nation great revival of the Chinese to decision-making, is a strategic project of long gas strong root thrift, consciousness is an important basic project, has a great influence in history education, has profound significance in the perspective of practical significance. To strengthen college students' core socialist values its education significance is very important, should become the socialism the content of the political and ideological education in colleges and universities.

\section{AT PRESENT, COLLEGES AND UNIVERSITIES OF THE EDUCATION OF SOCIALIST CORE VALUES OF PROBLEMS EXISTING IN THE PROCESS}

This article through to several universities for the understanding of the socialist core values of college students through investigation and analysis, and recognition after the analysis of the status quo, found that college students to understand and learn about the knowledge of the core values of socialism way very few, most college students in colleges and universities in the ideological and political theory only related to the classroom to learn to some shallow knowledge, daily life and common sense rarely come into contact with these theories, to promote the learning, but only a few students take the initiative to find relevant information, therefore, has quite part of college students don't know how many the socialist core values, knowledge is not enough, let alone recognition and grant access to, not to mention is the use of the core values of socialism to lead college students actual practices. Individual student socialism, lack of confidence, is skeptical of Marxism the serious influence western thought, diversified value orientation, values and the core value of socialism. Although these phenomena is not the mainstream of college students, but its negative influence and radiation should not be underestimated.

According to the above we can see that the current socialism core values of the actual effect of education in colleges and universities, there are also many unanswered questions need to be solved. We will through the investigation and analysis, these problems and its specific performance summarized seriously comb is as follows:

\section{A. First of all, the lack of enough attention}

Embodies the "integration" teaching is not enough. Many colleges and universities did not put the socialist core value system of education as an important part of talent training, can't be well integrated into the system of ideological and political theory course, more can't be well integrated into professional can manage service all aspects of the campus culture construction, suspected just collapses.

\section{B. Second, the lack of positive publicity}

Most university students' socialist core value system of theory education platform, mainly confined to the classroom and centralized organization of the ideological and political theory course each semester students active in classes, the channel is too narrow a positive publicity, propaganda is not enough.

\section{Again, the education idea}

For human-oriented ideological recognition is insufficient, lack of emotional aspects of the practice and experience, in related aspects, such as the concept of education development, cannot fully to urge and guide the values of college students.

Fourth, the ways and means of education is very backward. For example, some key universities teachers in the teaching of ideological and political theory is simple, the teaching content copied books, rather than the actual problem, does not pay attention to the real hot spots, unable to cause the students' interest in learning.

Fifth, the education support rich enough. In the socialist core values and the social practice and campus activities closely related aspects, such as is still very 
insufficient. Some school attaches great importance to the education theory, few organizations students' social practice, failed to give full play to the role of the second classroom, through the rich and colorful campus cultural life, to the broad masses of young students of socialist core values education.

Sixth, the construction of teaching material have defects. The lack of ideological and political theoretical strong easy to understand the readability of the textbooks.

Seventh, part of the quality of the ideological and political education can not meet the demand of new era.

\section{THE COLLEGES AND UNIVERSITIES OF SOCIALIST CORE VALUES EDUCATION ATTEMPT AND EXPLORE THE INNOVATION MODEL}

How to promote education concept, in order to solve this problem, the innovation education method, education support, to establish the socialist core values education and the actual demand, fully high effectiveness of grasp the law, is in front of difficult and complicated system engineering at the university, the university should have a full understanding. "12345" shows the education in the implementation of the practice pattern, will strengthen greatly improve the socialist core values education college of actual results. Here "12345" education mode, namely "to follow the rules, do two fusion, establishing three mechanism, adhere to the four combination, to build five big platform."

\section{A. To follow the rules}

Under the concept of innovative education in colleges and universities through the core values of socialism again, the whole process of the implementation of institutions of higher learning must follow from beginning to end, make the basic law of education, namely "perception - - practice - value" continuously promote the law of education. Only through education and indoctrination, let the student fully affirmed the socialist core values, accurately grasp the scientific connotation, in order to let students find them from bottom of my heart, and conscious effort to practice, and constantly deepen the understanding and the understanding in practice, finally reached the highest goal of education - the socialist core values become value and university student code of conduct. This would require the first university innovation education idea, student-centered teaching plan, pure, readability, interesting, life writing, teaching theory and practice, contains a profound truth, innovating teaching methods, enrich education support, to carry out the socialist core values education and form fo the college students, so that the students in the education activity of "learning" and "love", because "the real science" and "true understanding", and then gradually realize "faithful", "true", make the socialist core values to rise to their beliefs, as a company's intrinsic value and code of conduct.

\section{B. The two fusion earnestly}

In the socialist core values as a main idea to guide and pay attention to the values of college students, adhere to the two fusion is very important. First, the core values of socialism must be actively integrated into the college students' ideological and political theory class teaching system, give full play to the role of the main position, the perfect use of the channels. Believe in perfect and reform of the ideological and political education courses at the same time, the new set of teaching content, through the integration of the core values of socialism, in classroom teaching in colleges and universities, to promote the core values of socialism. Second, the teaching content of associated with the core values of socialism must be integrated into the teaching activities of the institutions of higher learning of various subjects, make it become the soul of the teaching, give full play of its as important educational ideology and the main role, so that the students can not only learn the professional knowledge, improve the political tutelage, still can undertake to the student through classroom teaching content reform, improve and guide the student, make its have the correct world outlook, values, outlook on life.

1) The establishment of three mechanisms: the system of socialist core values, to ensure that institutions of higher learning education goals effectively, therefore, institutions of higher learning must establish a "three mechanism". First, improve the overall penetration mechanism. For education in the socialist core values, the school should be the good education of ideological and political theory at the same time, efforts to carry out the "second class" education, the socialist core values education students learning content penetrated, and so on various aspects of social life of the core values of the university, the benign interaction with a variety of other ways to all occupied the main channel to create synergies, ideology and culture in order to increase the effectiveness of socialist core values education. Second, improve the service safeguard mechanism. First of all, to carry forward the socialist core value system of organization to strengthen. Second, must strengthen the socialist core values its power of education, enrich the teachers' team, efforts to improve the professional quality of teachers, positive urged work personnel's responsibility consciousness so as to improve the level of work. In addition, still should invest more funds, in order to ensure the smooth progress of education activities, provides sufficient funds safeguard system of socialist core values education. Finally, establish incentive mechanism. Shall establish effective evaluation index system of college students effectively to each evaluation of the ideological and political quality, the evaluation results into the students' comprehensive evaluation system, evaluate students, as a important basis of assessment of scholarship; Also can make hard and fast rules, students' ideological and political quality evaluation in the students' graduation, as a precondition for graduation, improve students' learning enthusiasm of socialist core values.

2) Adhere to the four combination: the innovation of teaching method, requires universities to insisted that "four combinations". First of all, the theory of education and social practice. And practical character of socialist core values, we should encourage students to society, social consciousness, social services, 
information, understand their needs, to understand public opinion and broaden their horizons, increase the experience, enhance their own ability, the core values of theory, in practice the socialist core value system of the essence, has a profound meaning, we must grasp its essential character, so that you can more easy to understand and learn and gradually raise their values and code of conduct. Therefore, to stick to the theory of education and social practice, education and guide the student to be firmly established in the social practice of socialist core value system. Second, combination of general education and targeted education. At the community college education of socialist core values, to pay attention to the relationship between universality and particularity, should not only pay attention to in full swing, full penetration education activities, but also pay attention to students' individual character development, emphasis on college students' individual needs. To adhere to the combination of education popularization and education of the pertinence, especially to solve specific problems of individual students, to better reflect the spirit, make education more deeply, get better grades. Third, the traffic with two-way one-way combination. Socialist core values education in colleges and universities break to instill the inherent mode of teacher, teaching method improvement and innovation, avoid talking the script style. Insist on the combination of traffic and two-way communication is one-way, more adopt heuristic teaching, scene teaching method and means, so that the students in the effective participation in the process of teaching, teachers and students, realize the bidirectional interaction, make teachers and students can communicate on the basis of equality, so as to promote the students' subjective dynamic role to play, for the promotion of teaching effectiveness significantly. Fourth, we must combine explicit education and implicit education organic. Here, the dominant education, refers to the dominant class teaching in the process of education, lectures, exhibitions, special website, positive, is directly related to the socialist core values and means of knowledge to the students, in order to realize the education method and the strategy of a very short period of time the desired results. Dominant education advantage is convenient, sinews; Defect is boring, easy to cause opposite, conflict and rejection. Recessive and dominant education and education just bring out the best in each other, and it is through a variety of activities, create a strong atmosphere, and so on. Ambiguous, make education and infection of environment, education influence imperceptibly, sublimate their own thoughts subtly. In university education of socialist core values, should give full play to instill a major characteristics of education, but also pay attention to good infiltration function of recessive education, adhere to explicit and implicit education education together constitute the complete system of socialist core values education of university, build a platform to study theory.

\section{REFERENCES}

[1] Su Jie The cultivation of the college students' socialist core values [J]. Science and technology innovation, 2013, 11:56-58.

[2] Wang Yunbo, Sun Yingyun, Jing Hongjun. University of innovation and entrepreneurship education system research [J]. Journal of century bridge, 2015 01:65-67.

[3] Zhang Tianhua Wang Xulong. Innovation in colleges and universities entrepreneurship education teaching resources development and research [J]. Journal of liaoning university of technology (social science edition), 2015, 75:75-78.

[4] Bai Yun. The practice of innovation in colleges and universities entrepreneurship education research [J]. Chinese and foreign entrepreneurs, 2015, 21:168.

[5] Yu Wen. Innovation in colleges and universities entrepreneurship education present situation and countermeasure research $[\mathrm{J}]$. The road to success, 2015) : 10-11.

[6] Cao Yang. Transformation of the mode of economic development under the background of innovation in colleges and universities entrepreneurship education research [D]. The northeast normal university, 2014.

[7] Chen Liang. Ideological education work of university innovation entrepreneurship education support - in nantong university, for example $[\mathrm{J}]$. Science and technology vision, 2014 preceding: $134+152$

[8] Wang Chengguo. Private colleges innovative entrepreneurship education present situation and countermeasure research [J]. Journal of heilongjiang local Chronicles, 2013, 23:289.

[9] of innovation and entrepreneurship education [M], Chen Jingliang - fudan university press, 2012:125-129.

[10] Introduction to entrepreneurship [M] . [10] innovation Ni Feng higher education press, 2012:145-147. 